\begin{tabular}{|c|c|c|c|cc|l|}
\hline \multirow{2}{*}{ A } & $\mathbf{C ~ P ~ E ~}$ & $\mathbf{1 4 3 7}$ & \multirow{2}{*}{$\mathbf{B}$} & Dispatch: 8.6.09 & Journal: CPE & CE: Lalitha/Sukanya \\
\cline { 2 - 3 } \cline { 5 - 6 } & Journal Name & Manuscript No. & & Author Received: & No. of pages: 11 & PE: Bindu/Mini \\
\hline
\end{tabular}

\title{
Effect of platelet-rich plasma on sinus lifting: a randomized- controlled clinical trial
}

Torres J, Tamimi F, Martinez P-P, Alkhraisat MH, Linares R, Hernández G, TorresMacho J, López-Cabarcos E. Effect of platelet-rich plasma on sinus lifting: a randomized-controlled clinical trial. J Clin Periodontol 2009; doi: 10.1111/j.1600051X.2009.01437.x.

\begin{abstract}
Objective: The combination of anorganic bovine bone $(\mathrm{ABB})$ with platelet-rich plasma (PRP) has been widely used in bone regeneration procedures although its benefits are still unclear. The purpose of this study was to evaluate whether or not PRP improves the efficacy of $\mathrm{ABB}$ in sinus floor augmentation. In addition, we have investigated the effect of residual bone height and tobacco on implant survival in sinus augmentation procedures.

Pateint and Methods: Eighty-seven patients recruited for this study underwent 144 sinus floor augmentation procedures using $\mathrm{ABB}$ alone or $\mathrm{ABB}$ plus $\mathrm{PRP}(\mathrm{ABB}+\mathrm{PRP})$ in a randomized clinical trial. A total of 286 implants were placed in the augmented bone, and their evolution was followed up for a period of 24 months. In order to investigate on a histological level and any adjunctive effects, we performed an ancillary study in five edentulous patients with a symmetrical severely resorbed maxilla. In these patients, a bilateral sinus augmentation was randomly performed using $\mathrm{ABB}$ or $\mathrm{ABB}+\mathrm{PRP}$ in a split-mouth design, and after 6 months, bone biopsies were taken from the implant sites for histological and histomorphometric analysis. Results: Overall, $96.2 \%$ of $\mathrm{ABB}$ and $98.6 \%$ of $\mathrm{ABB}+\mathrm{PRP}$ implant success were obtained during the monitoring period and differences were not found between sites grafted with and without PRP in the 87 patients studied. Densitometry assessments and graft resorption were similar in both experimental groups. However, the histological and histomorphometrical analysis in the five edentulous patients revealed that bone augmentation was significantly higher in sites treated with ABB $+\mathrm{PRP}(p \leqslant 0.05)$. Another outcome from our study is that the lack of initial bone support $(p \leqslant 0.05)$ and smoking $(p=0.05)$ appeared to have a negative effect on the treatment success, which was accentuated when both circumstances coincided.

Conclusions: PRP is not a determining factor for implant survival in sinus lifting procedures. However, this study revealed that PRP can improve the osteoconductive properties of $\mathrm{ABB}$ by increasing the volume of new bone formed. Moreover, in sinus augmentation procedures the implant's survival rate appears to be more influenced by the residual bone height or by tobacco than by the type of bone graft.
\end{abstract}

\author{
Jesús Torres ${ }^{1,2}$, Faleh Tamimi ${ }^{2,3}$, \\ Pedro-Pablo Martinez ${ }^{2}$, Mohammad \\ Hamdan Alkhraisat ${ }^{4}$, Rafael Linares ${ }^{1}$, \\ Gonzalo Hernández ${ }^{5}$, Juan \\ Torres-Macho ${ }^{6}$ and Enrique \\ López-Cabarcos ${ }^{4}$ \\ ${ }^{1}$ Ciencias de la Salud III, Universidad Rey \\ Juan Carlos, Alcorcón, Spain; ${ }^{2}$ Private \\ practice, Clinica Dental Alcalá, Madrid, \\ Spain; ${ }^{3}$ Faculty of Dentistry, McGill \\ University, Montreal, QC, Canada; ${ }^{4}$ Faculty \\ of Pharmacy, Universidad Complutense, \\ Madrid, Spain; ${ }^{5}$ Faculty of Dentistry, \\ Universidad Complutense, Madrid, Spain; \\ ${ }^{6}$ Hospital Infanta Cristina, Parla, Madrid
}

Key words: anorganic bovine bone; bone regeneration; platelet-rich plasma; sinus floor augmentation

Accepted for publication 10 May 2009
Conflict of interest and source of funding statement

There is no conflict of interests.

This work was supported by the Ministry of Science and Technology (grant MAT2006-13646-C03-01), the UCM
Programme for Research Groups, and the Spanish Agency of International Cooperation (AECI/A011152/07). Dr. F. Tamimi acknowledges a postdoctoral grant from the Spanish Foundation for Science and Technology (FECYT).

Dental implants' reconstruction of edentulous jaws with adequate bone volume and density has achieved a high level of reliability and a considerable rate of success (Adell et al. 1990). However, the quality of bone in the posterior maxillary regions often shows a low level of mineralization (type IV), and severe bone 


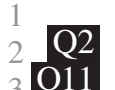

resorption, two factors that render the initial stability of dental implants difficult (Mish 1990, McCarthy et al. 2003). Besides, the volume of bone in this area is usually limited by the maxillary sinus pneumatization, hindering implant placement (Brånemark et al. 1984, Blomqvist et al. 1996).

The maxillary sinus-lift surgical technique increases the bone height in the posterior area, and enables the placement of implant-supported prostheses (Tatum 1986). This procedure involves the detachment of Shneider's membrane from the maxillary sinus floor, creating a space that is filled with a grafting material to promote a vertical bone augmentation into the maxillary sinus cavity.

Different grafting materials have been used to fill the space created between the superiorly repositioned sinus membrane and the floor of the maxillary sinus. Early studies advocated the use of autogenous bone in the augmented space (Boyne \& James 1980). However, its availability is restricted by the limited amount of intra-oral grafts, the morbidity associated with the second surgery at the donor site and the high cost for bone harvesting from extra-oral sites. Therefore, alternative graft materials have been developed, including demineralized (human) bone matrix (Groeneveld et al. 1999) anorganic bovine bone (ABB) (Valentini \& Abensur 2003), tricalcium phosphate (Zijderveld et al. 2005) or bioactive glass particles (Tadjoedin et al. 2000).

Bio-Oss ${ }^{\circledR}$ (Geistlich Biomaterials) is a biocompatible and osteoconductive (Benezra et al. 2002) ABB that provides an ideal scaffold for new bone formation (Hämerle et al. 1998, Piattelli et al. 1999). It has been extensively used in maxillary sinus floor augmentation (Valentini \& Abensur 2003, Wallace et al. 2005) with high clinical success rates (Carmagnola et al. 2003). However, the lack of osteo-inductive properties encouraged researchers to find ways of improving its performance in vivo, and the addition of platelet-rich plasma (PRP) has been assayed. PRP is an autologous fibrin adhesive with a high platelet concentration easily obtained from whole blood by centrifugation (Antonaides 1981, Marx et al. 1998, Anitua 1999). Furthermore, PRP has a high concentration of angiogenic and mitogenic growth factors implicated in bone healing, such as transforming growth factor (TGF) (Wikesjö et al. 1998), platelet-derived growth factor (PDGF) and insulin-like growth factor (Giannobile et al. 1996), and has been used in sinus floor elevation recently (Philippart et al. 2005, Consolo et al. 2007, Galindo-Moreno et al. 2007). Nevertheless, preliminary case reports using PRP as an adjuvant in bone regeneration procedures have been controversial (Anitua 1999, Roldán et al. 2004, Wiltfang et al. 2004, Kassolis \& Reynolds 2005, Philippart et al. 2005, Klongnoi et al. 2006a, b, Consolo et al. 2007, Galindo-Moreno et al. 2007) and no definitive conclusions have been drawn from them.

The ultimate procedure for evaluating the clinical advantages of a biomaterial is a controlled clinical trial. However, very few controlled clinical trials have been performed to evaluate the usefulness of combining PRP with osteoconductive materials for bone augmentation procedures. The aim of this study was to evaluate the effect of different variables such as a combination of $\mathrm{PRP}$ with $\mathrm{ABB}$, residual bone height and smoking on bone augmentation in sinus lift procedures. For this, two randomizedcontrolled clinical trials were carried out: an inter-patient clinical trial in a group of 87 patients and a split-mouth clinical trial conducted in a group of five patients. The control group consisted of maxillary sinus lifting with Bio-Oss ${ }^{\circledR}$ alone while the experimental group included sinus lifting with Bio-Oss ${ }^{\circledR}+$ PRP. The results were obtained by means of clinical investigation, radiographs, histologic and histomorphometric analysis.

\section{Patient and Methods \\ Patients}

\section{Inter-patient randomized-controlled clinical trial}

Patients were enrolled in the study on the basis of having insufficient bone height $(<7 \mathrm{~mm})$ in the posterior maxilla.
In these patients, sinus floor augmentation was planned to allow rehabilitation with fixed implant-supported prosthesis. Smokers were included in the study, while patients with severe systemic disease [American Society of Anaesthesiology (ASA) III or IV] and a previous history of chronic sinusitis were excluded. Informed written consent to participate in this study was obtained from all patients, in particular explaining the objectives and protocol of the study, and possible side effects. Before commencing this study, approval was obtained from the ethical committee for clinical trials of the "Hospital San Carlos" (Madrid, Spain), to carry out a pilot clinical study in the dental clinic "Clinica Dental Alcala”, (Madrid, Spain).

During the study period (2003-2008), 209 patients attended "Clinica Dental Alcala" demanding implant treatment. Among these patients, 87 were recruited for this randomized-controlled clinical trial on the basis of having $<7 \mathrm{~mm}$ of residual ridge in the posterior maxilla. Patients with residual bone height $<4 \mathrm{~mm}$ received a two-stage approach while patients with residual bone height $\geq 4 \mathrm{~mm}$ received a one-stage approach (Zinner \& Small 1996, Jensen et al. 1998). A total of 144 sinus floor augmentations were performed (Fig. 1). There was heterogeneity in the systemic diseases present in some of the selected patients, such as diabetes, heart failure and osteoporosis; however, none of these conditions are known to jeopardize the implant's success (Mombelli \& Cionca 2006). On the other hand, there are several authors who associate smoking with dental implant failure (Bain \& Moy 1993, De Bruyn \& Collaert 1994, Gorman et al. 1994, Wallace 2000, Chuang et al. 2002), which led us to consider this variable and to evaluate its effects on implant survival in sinus augmentation procedures. Patients who

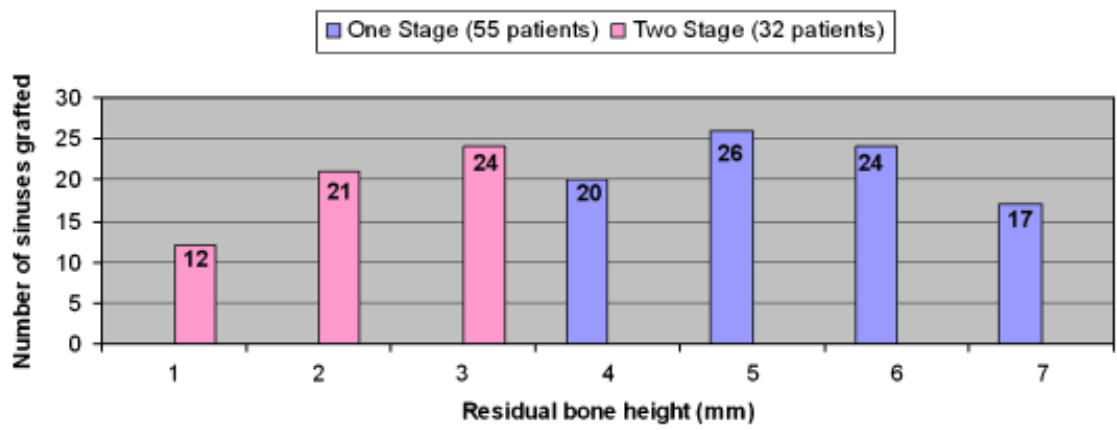

Fig. 1. Frequency distribution of the sinuses grafted as a function of residual bone height. 
reported smoking $>$ ten cigarettes/day were defined as smokers (Tonetti et al. 1995), while patients who reported smoking only occasionally were not considered to be smokers.

\section{Split-mouth randomized-controlled clinical trial}

In addition to the above-mentioned criteria, the inclusion criteria for the splitmouth study were patients with bilateral loss of teeth in the maxillary premolar and molar areas, and Cadwood classification V or VI (Cawood \& Howell 1991) that required a bilateral, twostage, sinus floor-lifting procedure (first stage, bone grafting; second stage, placement of implants) (Boyne \& James 1980).

Radiography (orthopantomography) and computed tomography (CT) were performed 6 months post-operatively on surgical sites, before and after treatment, and the bone density was quantified in both $\mathrm{PRP}+\mathrm{ABB}$ and $\mathrm{ABB}$ groups using SIMPlant 7 (Columbia Scientific, Columbia, MD, USA) software. Six selected zones in each maxillary sinus were chosen for a standardized evaluation (Rao \& Alfidi 1981). All five patients were edentulous for 7-10 years in the maxilla, which had insufficient retention for their upper denture with a residual alveolar ridge between 1 and $3 \mathrm{~mm}$ diagnosed by CT (see Fig. 2).

\section{Randomization}

The allocation of participants to intervention groups in a truly unpredictable, randomized sequence was performed by a computerized random number generated using GraphPadQuickCalc software (GraphPad Software Inc., La Joya, CA, USA), including the concealment of the

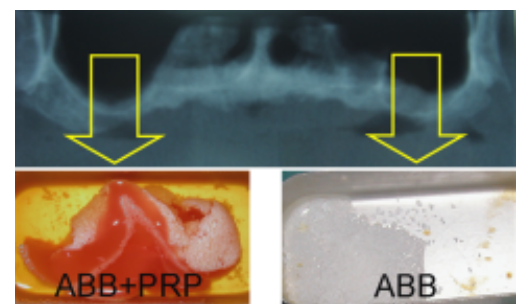

Fig. 2. Scheme of the split-mouth randomized method used in the controlled clinical trial. The upper panel shows a computed tomography of a patient before surgery. Randomly, one sinus was grafted with anorganic bovine bone $(\mathrm{ABB})$ alone and the other sinus was grafted with $\mathrm{ABB}$ plus platelet-rich plasma (lower panel). allocation schedule until the assignment was made. Subject numbers were assigned at the baseline examination in consecutive order by the principal investigator. The sample size used has been usual in pervious studies for this type of clinical evaluation. Patients included in the inter-patient clinical trial were allocated by a blinded assistant into two groups: the first was to be treated with $\mathrm{ABB}$ alone, and the second with $\mathrm{ABB}+\mathrm{PRP}$. On the other hand, each of the patients included in the split-mouth study was treated with $\mathrm{ABB}$ alone in the maxilla of one side and with $\mathrm{ABB}+\mathrm{PRP}$ in the contralateral one. The graft materials were randomly allocated for either side in each patient.

\section{Blinding}

The surgeon was blinded to the graft material applied to each patient before graft implantation. An assistant handled the PRP-ABB or the ABB group after the surgeon had already accessed the sinus and elevated the membrane. The histologist was blinded to the samples' groups throughout the histomorphometrical analysis.

\section{PRP}

PRP was prepared according to Anitua's method $^{15}$ (Anitua 1999). Blood was collected from all patients $30 \mathrm{~min}$ before starting the surgery to ensure that the blinding of the surgeon was maintained. In the $\mathrm{ABB}+\mathrm{PRP}$ group, between 10 and $20 \mathrm{~cm}^{3}$ of blood was withdrawn via venous aspiration into $4.5 \mathrm{~cm}^{3}$ test tubes and mixed with a $3.8 \%$ sodium citrate solution at a $5 / 1(\mathrm{v} / \mathrm{v})$ ratio, achieving anticoagulation through calcium binding. The blood was then centrifuged using a Bti ${ }^{\circledR}$ PRGF System II centrifuge (Bti Biotechnology Institute S.L., Vitoria, Spain) into three basic components: red blood cells (RBCs), PRP and plateletpoor plasma (PPP). Because of the different densities of the components, the RBC layer forms at the bottom of the tube, the PRP layer in the middle and the PPP layer at the top. A pipette (Gilson Inc., Middleton, WI, USA) was used to separate the layers, from the less dense to the denser. Therefore, PPP was separated first (about $2.25 \mathrm{~cm}^{3}$ ), followed by PRP (about $0.9 \mathrm{~cm}^{3}$ ), leaving the RBC layer as a residual (about $2.25 \mathrm{~cm}^{3}$ ).

Flow cytometry (ADVIA 120, Hematology system, Bayer, Leverkusen, Germany) was used for platelet counting.
Platelet counts were $2.97 \pm 0.7$-fold over peripheral blood, confirming that the PRP preparation technique used in this study produced a source of highly concentrated platelets. The average peripheral blood platelet count was $275.000 \pm 58.000 / \mu \mathrm{l}$. Before its surgical application, PRP $(0.2 \mathrm{ml})$ was activated with a $30 \% \mathrm{CaCl}_{2}$ solution, and a PRP gel was obtained and mixed with $\mathrm{ABB}(\sim 1.5 \mathrm{~g})$.

\section{Surgical protocol}

Because of the insufficient bone height for implant stabilization, in all cases, the sinus floor augmentation was prepared following the method described by Boyne \& James (1980) and Tatum (1986). The decision to place simultaneous or delayed implants depended on whether or not the residual crest had enough bone height to permit primary implant stability (Zinner \& Small 1996, Jensen et al. 1998).

The osteotomy of the lateral wall of the maxilla was performed under local anaesthesia, and the entire buccal plate was removed before the elevation of the sinus membrane and the implantation of the assigned graft material. No membranes were used to cover the lateral wall defect after the bone substitute was placed. In the two-stage sinus augmentation procedure, a healing time of 6 months was allowed before implant placement (Osseotite, Biomet 3 i Inc., Palmbeach, FL, USA).

Post-operatively, antibiotics, anti-inflammatory and antiseptics were prescribed, and sutures were removed 1 week after surgery. Patients were instructed not to wear their prosthesis for 2-3 weeks after surgery. For the next 4 months, the existing upper prosthesis was adapted to the maxilla for aesthetics and relined periodically with a soft tissue conditioner. All patients were required to follow a soft diet and no mastication was permitted.

\section{Histological and histomorphometric procedures}

The histological and histomorphometic analysis was performed in the five patients recruited for the split-mouth randomized clinical trial. In these patients, bone biopsies were obtained from both treated sites. After a healing period of 6 months, these patients were called for implant placement and biopsies were retrieved from dental-implant sites using a trephine burr $(\varnothing=3.0 \mathrm{~mm}$ $\times 10.0 \mathrm{~mm}$ in length) (see Fig. 3). 
Subsequently, the biopsies were fixed in $10 \%$ formaldehyde $(\mathrm{pH} 7.4)$ and stored at $4{ }^{\circ} \mathrm{C}$. After dehydration in ascending series of alcohol (60-100\%), biopsies were embedded in 2-hydroxy-ethylmethacrylate (Technovit, Leica Microsystems GMBH, Wetzlar, Germany), then photopolymerized for $6 \mathrm{~h}$ with ultraviolet light, $2 \mathrm{~h}$ with white light and $6 \mathrm{~h}$ with blue light into ready-tocut sample blocks.

A saw microtome Exakt ${ }^{\circledR}$ (Leica Microsystems $\mathrm{GmbH}$ ) was used to cut 200- $\mu$ m-thick coronal sections from the cylinders. Thereafter, the sections were ground to a thickness of $40-50 \mu \mathrm{m}$ by means of a grinder Exakt ${ }^{\circledR}$ (EXAKT, Norderstedt, Germany) to achieve better histological visualization without risking the loss of the samples. Afterwards, surface staining was performed with basic fuchsine and methylene blue (Donath \& Breuner 1982). The histological evaluation of bone neoformation was carried out by means of optical microscopy. The histomorphometric analysis was performed using light micrographs (at magnification $\times 6$ ) of the biopsy slices, which were captured with a digital camera and analysed with the histomorphometric software MIP-4 (Digital Image System, Barcelona, Spain). The sections were analysed by a single examiner blinded to the bone graft material and the following measurements were taken from each sample: newly formed bone volume (NB), soft tissue volume (ST) and residual graft volume (RG). The measurements were expressed as percentages of the total sample volume.

$$
\begin{aligned}
\mathrm{NB}(\%)= & \frac{\text { Newly formed bone volume }}{\text { Total sample volume }} \\
& \times 100 \\
\mathrm{ST}(\%)= & \frac{\text { Soft tissue volume }}{\text { Total sample volume }} \times 100 \\
\mathrm{RG}(\%)= & \frac{\text { Residual graft volume }}{\text { Total sample volume }} \times 100
\end{aligned}
$$

\section{Statistical analysis}

The distribution of the patients' systemic conditions (diabetes, smoking, etc.) among clinical treatments' groups was assessed using the $\chi^{2}$ test, in order to evaluate comparability between groups. Moreover, two-way analysis of variance tests, in the univariate analysis, were used to find any association between patients' (i) systemic conditions and (ii) treatment on the one hand and (i) implant survival and (ii) patient treatment success on the other. A multiple stepwise logistic regression analysis was performed to assess the joint contribution of the smoking behaviour and residual bone height to implant survival. Histomorphometric measurements of the biopsies taken from the grafted sites were compared within each patient using a $t$-test for paired samples. For all univariate analyses, a $p \leqslant 0.05$ was chosen. A statistical software package (SPSS 17.0, SPSS, Chicago, IL, USA) was used for the statistical analysis.

\section{Results}

Inter-patient-controlled clinical trial

This study started in January 2003 and ended by June 2005. The group of 87 patients selected for the inter-patient study consisted of 47 females and 40 males with an age range between 52 and 78 years (see Table 1). The presence of systemic disorders was registered among the study groups. The distribution of systemic disorders was balanced among the different treatment groups (Fig. 4).

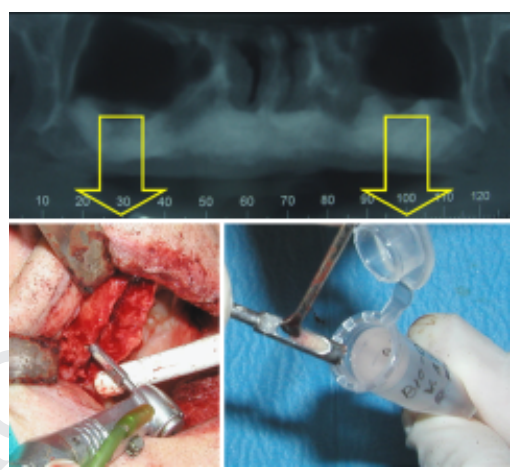

Fig. 3. The upper panel shows a computed tomography of the augmented sinus. The lower panel shows the harvesting of bone biopsies 6 months after sinus floor augmentation with a

\begin{tabular}{|c|c|c|c|c|c|}
\hline & \multirow{2}{*}{$\begin{array}{c}\text { Total number } \\
\text { of patients }\end{array}$} & \multicolumn{2}{|c|}{ Residual bone height } & \multicolumn{2}{|c|}{ Type of graft } \\
\hline & & $\begin{array}{l}\text { one stage } \\
(4-7 \mathrm{~mm})\end{array}$ & $\begin{array}{l}\text { two stage } \\
(<4 \mathrm{~mm})\end{array}$ & $\mathrm{ABB}+\mathrm{PRP}$ & $\mathrm{ABB}$ \\
\hline Male & $40(46)$ & $24(60 \%)$ & $16(40 \%)$ & $31(50 \%)$ & $31(50 \%)$ \\
\hline Female & $47(54)$ & $31(66 \%)$ & $16(34 \%)$ & $43(52.4 \%)$ & $39(47.6 \%)$ \\
\hline Smoker & $31(35)$ & $18(58 \%)$ & $13(42 \%)$ & $22(50 \%)$ & $22(50 \%)$ \\
\hline Non-smoker & $56(65)$ & $38(67.8 \%)$ & $18(32.2 \%)$ & $51(52 \%)$ & $47(48 \%)$ \\
\hline Diabetes type I & $4(4.5)$ & $3(75 \%)$ & $1(25 \%)$ & $4(57 \%)$ & $3(43 \%)$ \\
\hline Diabetes type II & $5(6)$ & $2(50 \%)$ & $2(50 \%)$ & $4(44.4 \%)$ & $5(55.6 \%)$ \\
\hline Osteoporosis & $11(12.6)$ & $5(45.4 \%)$ & $6(54.6 \%)$ & $11(55 \%)$ & $9(45 \%)$ \\
\hline Ischaemic heart disease & $7(8)$ & $3(43 \%)$ & $4(57 \%)$ & $5(45.4 \%)$ & $6(54.6 \%)$ \\
\hline Hypertension & $14(16)$ & $8(57.2 \%)$ & $6(42.8 \%)$ & $10(50 \%)$ & $10(50 \%)$ \\
\hline
\end{tabular}
trephine bur of $3 \mathrm{~mm}$ diameter for histologic and hiostomorphometric examination.

Table 1. Distribution of patients by systemic disorder into assigned treatment groups

Data are presented in absolute number (percentage).
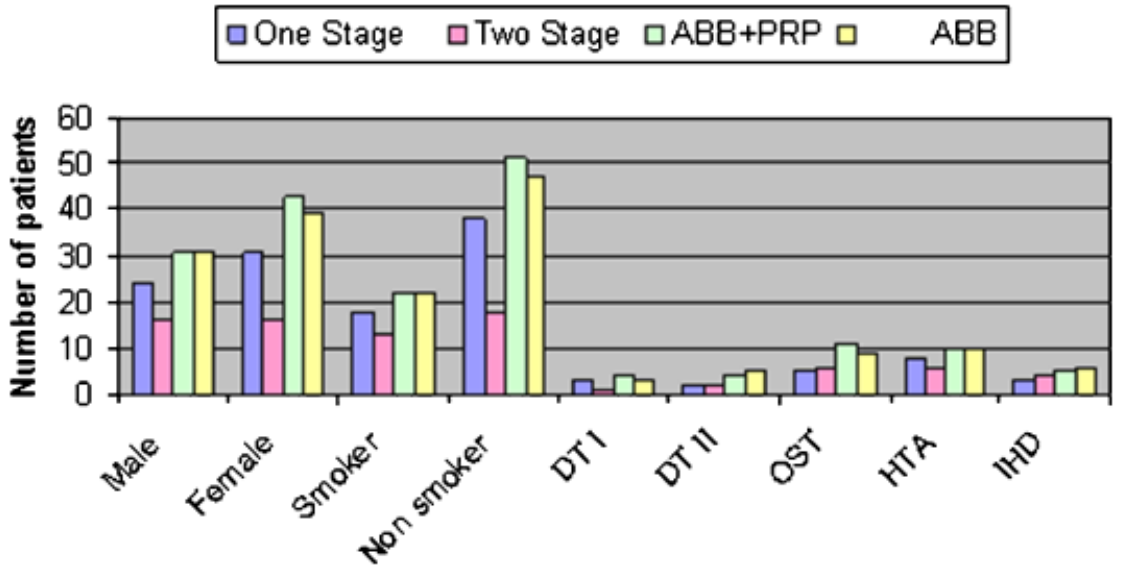

Fig. 4. Distribution of patients' demography as a function of residual bone height and type of graft. DT I, diabetes type I; DT II, diabetes type II; OST, osteoporosis; HTA, hypertension; and IHD, ischaemic heart disease. 
Among the study groups, 144 sinus floor augmentations were performed to receive a total of 286 implants (10$13 \mathrm{~mm}$ long). The implantation was deferred in 57 sinuses and immediate in 87 . Table 2 summarizes the results obtained.

Healing was uneventful in all patients because none of them complained of significant pain and no signs or symptoms of infection were reported. All sinus-augmented sites allowed the installation of one to three rough-surfaced implants (Osseotite, Biomet 3i Inc.) with diameters between 3.75-5 and $10-13.0 \mathrm{~mm}$ long. Radiological images show that all implants displayed full-bony integration (see Fig. 5). Six months after their insertion, the implants were uncovered and the patients were rehabilitated with fixed bridge prostheses. After the 24-month follow-up period, $98.6 \%$ of the patients treated with $\mathrm{PRP}+\mathrm{ABB}$ and $96.2 \%$ of those treated with $\mathrm{ABB}$ presented implant survival.

This table shows that therapeutic groups were balanced on the basis of smoking, gender, type of augmentation and residual bone height to confirm that randomization worked.

\section{Surgical complications}

Sinus membrane dehiscence was observed in five cases (5.74\%) and all of them were small perforations $(\leqslant 5 \mathrm{~mm})$. In the three cases observed in the $\mathrm{PRP}+\mathrm{ABB}$ group, the dehiscence was sealed using PRP alone whereas a collagen membrane was used in the ABB group (Fig. 6). One adverse result in outcome survival was associated with sinus membrane dehiscence in a second-stage augmentation procedure grafted with ABB.

\section{Type of bone graft}

The adhesive capacity of fibrin in $\mathrm{PRP}+\mathrm{ABB}$ facilitates the handling of the graft material as compared with the particles of $\mathrm{ABB}$ alone, making the filling of the sinus cavity easier (see Fig. 7).

\section{Survival of grafts}

Graft survival at the secondary surgery was sufficient to allow implant placement in all the patients included in the study. However, we found that in five cases partial loss of bone graft occurred probably because membrane coverage was not used (Fig. 8).

Table 2. Distribution of patients, sinuses and implants by residual maxillary bone height and graft type

\begin{tabular}{|c|c|c|c|c|}
\hline \multirow[t]{3}{*}{ Type graft } & \multicolumn{4}{|c|}{ Residual bone height } \\
\hline & \multicolumn{2}{|c|}{ one stage $(4-7 \mathrm{~mm})$} & \multicolumn{2}{|c|}{ two stage $(<4 \mathrm{~mm})$} \\
\hline & $\mathrm{PRP}+\mathrm{ABB}$ & $\mathrm{ABB}$ & $\mathrm{PRP}+\mathrm{ABB}$ & $\mathrm{ABB}$ \\
\hline \multicolumn{5}{|l|}{$N$ patients } \\
\hline Unilateral intervention & 11 & 9 & 4 & 3 \\
\hline Bilateral intervention & 32 & 32 & 25 & 25 \\
\hline Total & 55 & & 32 & \\
\hline$N$ sinuses grafted & 45 & 42 & 29 & 28 \\
\hline$N$ implants placed implant survival (\%) & $174(99.4)$ & 28 & $\begin{array}{l}112(94.6)^{*} \\
7.5)\end{array}$ & \\
\hline
\end{tabular}

*Significantly lower than surgical sites with higher residual bone height.
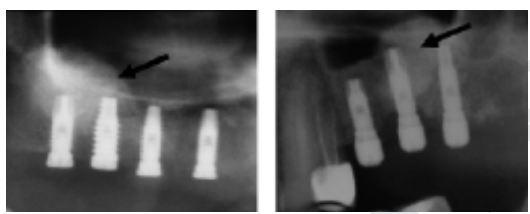

Fig. 5. Radiological images showing completed coverage of the implants into the augmented sinus (black arrows).
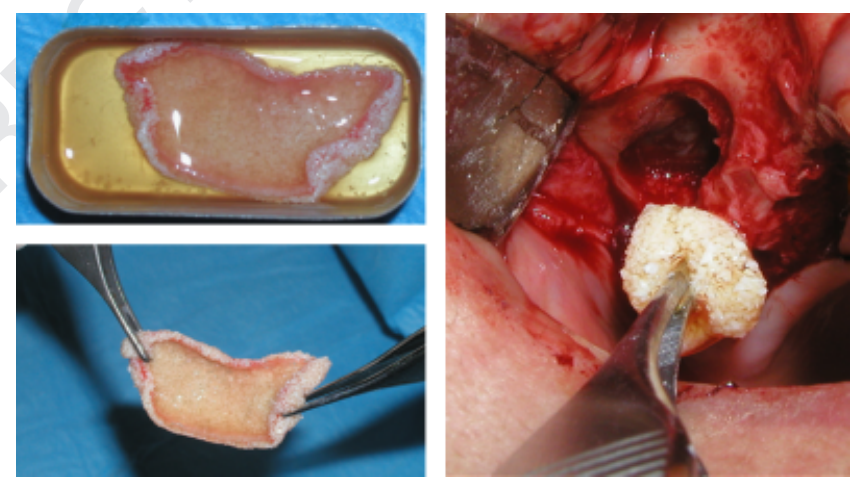

Fig. 7. The adhesive capacity of platelet-rich plasma improves the handling of anorganic bovine bone and facilitates the filling of the sinus cavity.

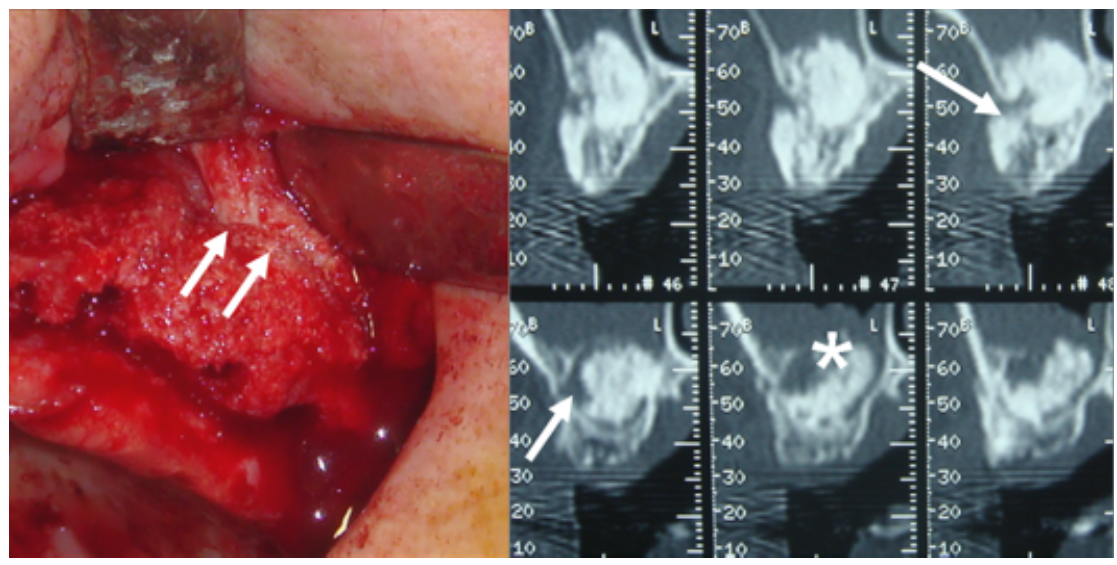

Fig. 8. Absence of membrane coverage of the buccal plate of the maxilla after filling the cavity resulted in a residual space filled with connective tissue (white arrows) and partial loss of bone graft $\left(^{*}\right)$ in some patients. However, we did not observe an excessive graft loss that may compromise implant placement at second-stage surgery in any patient. 


\section{Survival rates}

Implant survival is defined as the implant remaining in situ during the entire observation period. In this study, out of over 286 implants placed, 279 remained in situ during the entire observation period, being tested independently for absence of mobility, and seven failed, which yielded $97.5 \%$ implant survival. We found differences between the one- and two-stage surgery groups, indicating that the residual height could affect the survival rate. Furthermore, six implants were lost at sites with residual bone height $<4 \mathrm{~mm}$, while only one was lost at sites with residual bone height between 4 and $7 \mathrm{~mm}$. This result indicates that the amount of residual bone height significantly influenced the implant survival after sinus augmentation $(p \leqslant 0.05)$; however, the bone graft type seemed to have no effect on implant survival. Implant failure was higher before prosthetic loading, and in smokers (see Table 3). Indeed, five out of the seven failed implants occurred in four smoking patients $(p>0.05)$. The details of the implant's failure in the inter-patient study are given in Table 4 .

Treatment success rate was defined as the rate of patients that presented complications during the observation period. According to this definition, $92.8 \%$ of the patients' treatments were successful. Moreover, treatments' success seemed to be higher in patients with more residual bone height $(p=0.05)$, and in non-smokers $(p \leqslant 0.05)$.

Moreover, a $<4 \mathrm{~mm}$ residual bone height and smoking had a combined negative effect on the treatment success rate, although these differences did not reach statistical significance in the univariate and multivariate analyses (see Table 5).

Both the patient-based and the implant-based statistical analysis of the treatment groups agreed on the negative effect that both smoking and reduced residual bone height had on the implant survival and treatment success. Although there was no significant interaction between the two effects, the data suggested that the negative effect on the treatment success was accentuated when both circumstances coincided.

\section{Split-mouth-controlled clinical trial}

The five patients included in the splitmouth-controlled clinical trial received

Table 3. Implant distribution, failure and survival as a function of the residual maxillary bone height, bone substitute material and smoking behaviour

\begin{tabular}{|c|c|c|c|c|c|c|}
\hline \multirow[t]{3}{*}{ Type graft } & \multicolumn{6}{|c|}{ Residual bone height } \\
\hline & \multicolumn{3}{|c|}{ one stage $(4-7 \mathrm{~mm})$} & \multicolumn{3}{|c|}{ two stage $(<4 \mathrm{~mm})$} \\
\hline & $\begin{array}{c}\mathrm{PRP}+ \\
\mathrm{ABB}\end{array}$ & $\mathrm{ABB}$ & $\begin{array}{c}\text { implant } \\
\text { survival }(\%)\end{array}$ & $\begin{array}{c}\mathrm{PRP}+ \\
\mathrm{ABB}\end{array}$ & $\mathrm{ABB}$ & $\begin{array}{l}\text { implant } \\
\text { survival }(\%)\end{array}$ \\
\hline $\begin{array}{l}\text { Implants placed in smoking } \\
\text { patients }\end{array}$ & $34(1)$ & $32(0)$ & 98.4 & $24(1)$ & $20(3)$ & 90.9 \\
\hline $\begin{array}{l}\text { Implants placed in non-smoking } \\
\text { patients }\end{array}$ & $61(0)$ & $47(0)$ & 100 & $34(0)$ & $30(2)$ & $96.9^{*}$ \\
\hline Total $n$ implants placed & $95(1)$ & $79(0)$ & 99.4 & $58(1)$ & $50(5)$ & 95.0 \\
\hline Implant survival $(\%)$ & 98.9 & 100 & 99.4 & 98.2 & $90.7^{* * *}$ & 95.0 \\
\hline
\end{tabular}

(), number of failed implants;

*Significantly different from smokers $(p \leqslant 0.05)$;

** Implant survival significantly lower than in sinuses treated with PRP+ABB $(p \leqslant 0.05)$

Table 4. Details of patients with failed implants in the inter-patient study

\begin{tabular}{lccccccc}
\hline Gender & $\begin{array}{c}\text { Age } \\
\text { (years) }\end{array}$ & $\begin{array}{c}\text { Surgical } \\
\text { stages }\end{array}$ & $\begin{array}{c}\text { Bone } \\
\text { graft }\end{array}$ & $\begin{array}{c}\text { Membrane's } \\
\text { dehiscence }\end{array}$ & $\begin{array}{c}\text { Smoking } \\
\text { behaviour }\end{array}$ & $\begin{array}{c}\text { Failure implant's } \\
\text { position }\end{array}$ & $\begin{array}{c}\text { Time of } \\
\text { failure }\end{array}$ \\
\hline $\mathrm{M}$ & 67 & 1 & $\mathrm{PRP}+\mathrm{ABB}$ & $\mathrm{ND}$ & Yes & 25 & $\mathrm{BL}$ \\
$\mathrm{F}$ & 65 & 2 & $\mathrm{ABB}$ & $\mathrm{ND}$ & $\mathrm{Yes}$ & 16 & $\mathrm{FYL}$ \\
$\mathrm{M}$ & 71 & 2 & $\mathrm{ABB}$ & $\mathrm{D}$ & $\mathrm{Yes}$ & 26,27 & $\mathrm{BL}$ \\
$\mathrm{F}$ & 63 & 2 & $\mathrm{PRP}+\mathrm{ABB}$ & $\mathrm{ND}$ & $\mathrm{Yes}$ & 17 & $\mathrm{FYL}$ \\
$\mathrm{F}$ & 75 & 2 & $\mathrm{ABB}$ & $\mathrm{ND}$ & No & 15,16 & $\mathrm{BL}$ \\
\hline
\end{tabular}

BL, before prosthetic loading; FYL, failure during first year of prosthetic loading; ND, no dehiscence; D, dehiscence.

Table 5. Distribution of patients by residual maxillary bone height and smoking behaviour

\begin{tabular}{llcc}
\hline & Smoking & Non- smoking & \multicolumn{1}{c}{ Total } \\
\hline One stage $(4-7 \mathrm{~mm})$ & $19(94.8)$ & $36(100)$ & $55(98.2)$ \\
Two stage $(<4 \mathrm{~mm})$ & $12(75)$ & $20(95)$ & $32(87.5)^{* * *}$ \\
Total & $31(87.1)^{*}$ & $56(98.2)$ & $87(92.8)$ \\
\hline
\end{tabular}

(), treatment success rate in \%;

*Significantly lower $(p \leqslant 0.05)$ than non-smokers;

**Significantly lower $(p \leqslant 0.05)$ than one-stage treated patients.

Table 6. Patient, implants and graft data for the split mouth clinical trial

\begin{tabular}{|c|c|c|c|c|c|c|c|c|}
\hline \multirow[t]{2}{*}{ Patient } & \multirow[t]{2}{*}{ Gender } & \multirow[t]{2}{*}{$\begin{array}{l}\text { Age } \\
\text { (years) }\end{array}$} & \multicolumn{2}{|c|}{$\begin{array}{c}\text { Preoperative } \\
\text { bone height } \\
(\mathrm{mm})\end{array}$} & \multirow[t]{2}{*}{$\begin{array}{l}\text { Healing time } \\
\text { (months) }\end{array}$} & \multicolumn{2}{|c|}{$\begin{array}{l}\text { Postoperative } \\
\text { bone height } \\
(\mathrm{mm})\end{array}$} & \multirow[t]{2}{*}{$\begin{array}{c}\text { Implants' } \\
\text { position }\end{array}$} \\
\hline & & & $\mathrm{PRP}+\mathrm{ABB}$ & $\mathrm{ABB}$ & & $\mathrm{PRP}+\mathrm{ABB}$ & $\mathrm{ABB}$ & \\
\hline 1 & M & 55 & 2 & 3 & 6 & 13 & 13 & $14,16,25,26$ \\
\hline 2 & $\mathrm{~F}$ & 67 & 1 & 1 & 6 & 11 & 10 & $\begin{array}{l}14,15,16 \\
24,26,27\end{array}$ \\
\hline 3 & M & 62 & 2 & 2 & 6 & 11 & 10 & $\begin{array}{c}14,16,17 \\
25,26,27\end{array}$ \\
\hline 4 & $\mathrm{~F}$ & 58 & 1 & 3 & 6 & 12 & 13 & $\begin{array}{c}15,17 \\
16,17\end{array}$ \\
\hline 5 & $\mathrm{~F}$ & 64 & 3 & 2 & 6 & 14 & 12 & $\begin{array}{l}15,16,17 \\
25,26,27\end{array}$ \\
\hline
\end{tabular}

10 sinus floor augmentations with a total of 26 implants. A summary of the results obtained from these patients is presented in Table 6 .
After 6 months, CT showed no significant differences between ABB- and PRP+ABB-treated sites (see Fig. 9). In both cases, the augmented bone pre- 
sented adequate volume for implant placement, and both sites showed a similar radiographic aspect. Similarly, densitometric assessment showed no significant differences between both treatment modalities (see Fig. 10). The height of the augmented bone was similar in both groups: $10.4 \pm 0.7$ and $9.4 \pm 0.7 \mathrm{~mm}$ in $\mathrm{PRP}+\mathrm{ABB}$ and $\mathrm{ABB}$, respectively.

Upon histological observation, all biopsies revealed the presence of trabecular bone and remaining $\mathrm{ABB}$ granules within the treated maxillary sinuses (see Fig. 11). Differences between native pre-existing bone and newly formed bone were clearly observed because of the presence of $\mathrm{ABB}$ particles in the whole augmented area. On the surfaces of $\mathrm{ABB}$ particles, newly formed bone and connective tissue were present. The growth of bone took place mainly through the guidance of ABB particles from the pre-existing bone surface of the sinus floor along the augmented area,

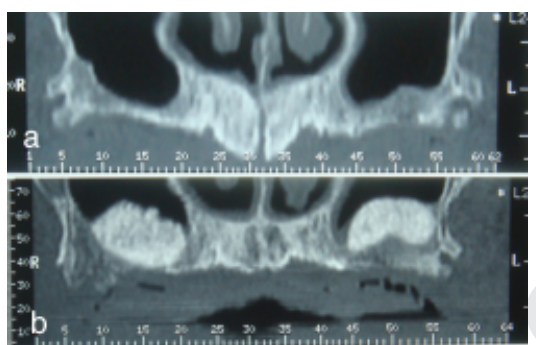

Fig. 9. Computed tomography of the same patient before (a) and 6 months after (b) surgery. The right sinus was grafted with $\mathrm{PRP}+\mathrm{ABB}$, and the left sinus was grafted with $\mathrm{ABB}$ alone. $\mathrm{ABB}$, anorganic bovine bone; PRP, platelet-rich plasma.

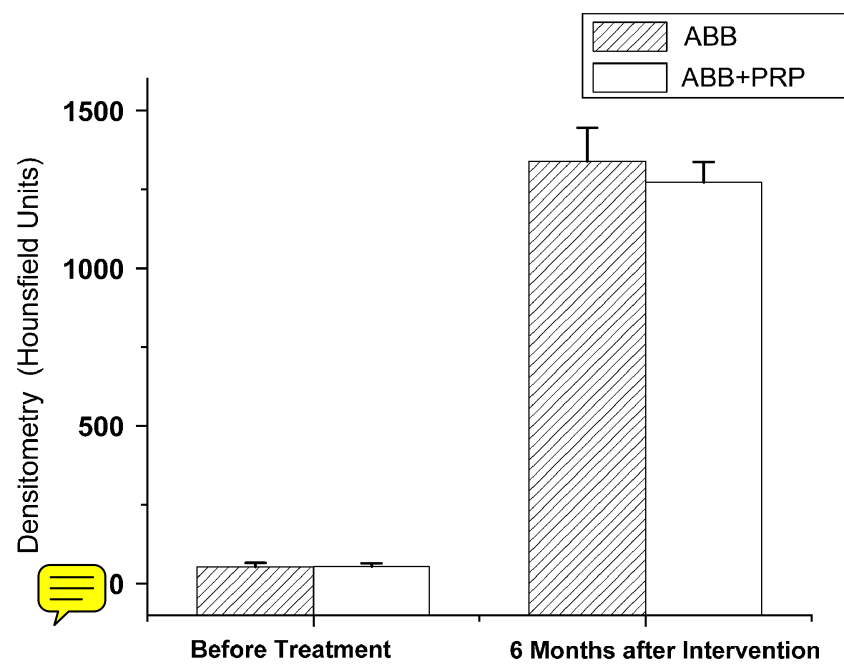

Fig. 10. Densitometry of maxillary sinuses before treatment, and 6 months after initial intervention in the patients included for the split-mouth clinical trial.

and bridges of woven bone between the grafted particles could be observed, connecting them into a mass of mineralized tissue (see Fig. 12). We also observed newly formed bone even in the most apical part of the samples. Bone formation around the grafted bone particles $(\mathrm{ABB})$ was seen in both the PRP and the non-PRP group. Furthermore, as shown in Fig. 13, the resorption of $\mathrm{ABB}$ particles is low.

Histomorphometric analysis revealed that the area occupied by newly formed bone was higher in the sites treated with PRP, while the average areas occupied by $\mathrm{ABB}$ particles were almost the same in the two groups (see Fig. 14).
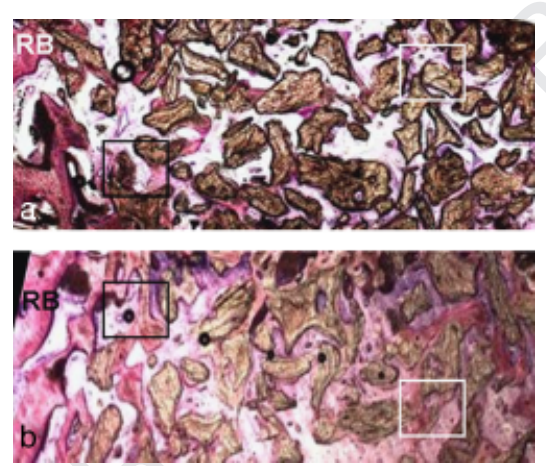

Fig. 11. Histological overview of biopsies taken from the sinus of patient 2 in Table 7, showing residual bone (RB) and two squares delimiting coronal (dark square) and apical (white square) sites of the sample, where new bone formation appears between $\mathrm{ABB}$ particles in both groups: the one treated with $A B B$ alone (a) and the one treated with $\mathrm{PRP}+\mathrm{ABB}(\mathrm{b})$. (Original magnification $\times 2.5$.) $\mathrm{ABB}$, anorganic bovine bone; PRP, platelet-rich plasma.

\section{Discussion}

Although sinus lifting is a reliable technique for vertical bone augmentation in the posterior maxilla, implant loss is still registered as often as in $17 \%$ of the patients with less than $6 \mathrm{~mm}$ residual bone height (Tonetti \& Hämmerle 2008). For this reason, bioactive agents are being tested in order to improve the clinical outcome of these procedures (Palmer et al. 2008).

Platelets are a natural source of growth factors with beneficial effects on tissue healing (Lynch et al. 1991, Giannobile et al. 1996, Wikesjö et al. 1998, Anitua et al. 2004); however, the use of PRP in bone regeneration in humans is a moot question (Anitua 1999, Roldán et al. 2004, Wiltfang et al. 2004, Kassolis \& Reynolds 2005 , Philippart et al. 2005, Klongnoi et al. 2006a, b, Consolo et al. 2007, GalindoMoreno et al. 2007). Recent systematic reviews of randomized-controlled clinical trials combining PRP with grafting materials still show conflicting and inconclusive results (Palmer et al. 2008). The controversy extends to animal studies because in some of them, significant benefits have been reported
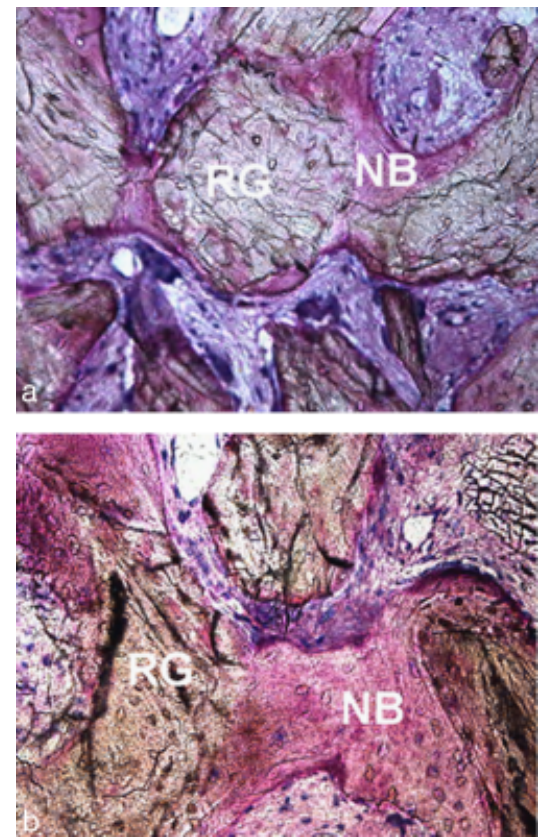

Fig. 12. Image of patient 3 of Table 7. Bone formation took place in the coronal part of the biopsy in both groups (a) $\mathrm{PRP}+\mathrm{ABB}$ and (b) $\mathrm{ABB}$ alone. The presence of new bone (NB) surrounding $A B B$ particles (RG, residual graft) and creating bridges between $\mathrm{ABB}$ particles can be observed in both groups. (Original magnification $\times 20$.) ABB, anorganic bovine bone; PRP, platelet-rich plasma. 

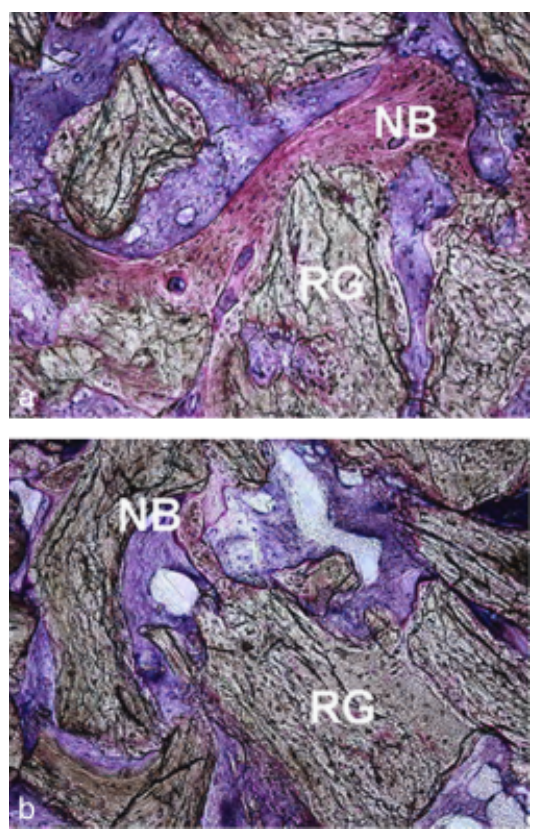

Fig. 13. Image of patient 5 of Table 7. Bone formation occurred in the apical part of the biopsy in both groups (a) PRP+ABB and (b) $\mathrm{ABB}$ alone. Although new bone formation (NB) was observed in both groups, even in the most apical part of the biopsies, more new bone appears in the $\mathrm{PRP}+\mathrm{ABB}$ group. We also observed a decrease in the number of bone bridges between ABB particles (RG, residual graft) compared with the coronal part of biopsies in the two groups (original magnification $\times 10)$. $\mathrm{ABB}$, anorganic bovine bone; PRP, platelet-rich plasma.

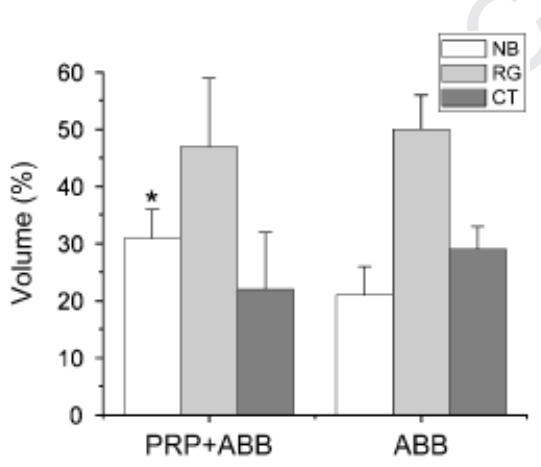

Fig. 14. Histomorphometric analysis of maxillar sinuses 6 months after initial intervention in the patients included for the splitmouth clinical trial. NB, new bone; RG, residual graft; $\mathrm{CT}$, connective tissue.

with the use of PRP mixed with bone substitutes in sinus lift procedures (Kassolis et al. 2000, Rodriguez et al. 2003, Mazor et al. 2004, Kassolis \& Reynolds 2005), whereas other studies have not shown any beneficial effect (Aghaloo et al. 2002, 2005, Fürst et al. 2003, Jakse et al. 2003, Butterfield et al.
2005, Klongnoi et al. 2006a, b, Roldán et al. 2008).

One possible explanation for the disagreement could be attributed to the different number of centrifugations used for preparing PRP (one or two centrifugations) (Marx et al. 1998, Anitua 1999). The main advantage of one centrifugation technique is the minimum leucocyte count and lesser concentration of PDGF and TGF- $\beta$ in comparison with two centrifugation techniques. The absence of leucocytes is important because neutrophils are a source of matrix metalloproteinases (MMP-8 and -9) and secrete other proteases, such as elastases that are destructive for growth factors (Anitua et al. 2008). Moreover, in the two centrifugation techniques, there are different methods for cell separation (Weibrich et al. 2002a, b, 2003a, b, 2004) that lead to significant differences in the amounts of cells (platelets and leucocytes) and levels of growth factors in the PRP samples (Weibrich et al. 2003a, b).

The concentration of platelets seems to play an important role in the regenerative process. Thus, PRP with an intermediate concentration of platelets (two to sixfold from peripheral blood) have shown beneficial effects, while lower (0.5-1.5-folds) and higher (911-folds) concentrations did not demonstrate beneficial effects (Weibrich et al. 2004). Herein, the centrifugation technique concentrates platelets to $2.9 \pm$ 0.7-fold over peripheral blood, supporting a desirable effect of PRP.

After 6 months of treatment, our results did not show significant differences between densitometric values of the augmented areas between both groups. Raghoebar et al. (2005) obtained similar results although other studies report higher densitometric values for the PRP sites (Marx et al. 1998, Consolo et al. 2007). However, some clinical studies indicate the ineffectiveness of PRP in sinus augmentation procedures (Danesh-Meyer et al. 2001, Raghoebar et al. 2005, Thor et al. 2007, 2005, Schaaf et al. 2008). Very few of these studies were proper randomized-controlled clinical trials (Froum et al. 2002, Raghoebar et al. 2005, Thor et al. 2005, 2007, Consolo et al. 2007, Galindo-Moreno et al. 2007, Plachokova et al. 2008). Four of these authors used a split-mouth design to evaluate the bone regeneration in sinus floor elevation using PRP as the unique variable. Raghoebar observed, in a split-mouth study on sinus floor elevations, that bone augmentation with autogenous grafts did not increase significantly on adding PRP $(41.1 \%$ at the nonPRP group and $38.4 \%$ at the PRP group) (Raghoebar et al. 2005).

Thor et al. (2007) observed a conspicuous increase in new bone formation obtained by combining PRP with an autogenous bone during early healing stages (3 months). Moreover, Consolo et al. (2007) suggest certain regenerative potential of PRP when used with an autologous bone but no statistical differences were observed between sites treated or not treated with PRP.

Hence, these results confirm the absence of consensus regarding the usefulness of combining autogenous bone with PRP; the same conflicting results appear when PRP is added to ABB. For instance, Froum et al. (2002) did not observe any benefit from combining PRP with $\mathrm{ABB}$ in three bilateral human sinus floor elevation procedures. Galindo-Moreno et al. (2007) using a composite graft of cortical autogenous bone, bovine bone and PRP in sinus floor elevations in humans, observed $34 \pm$ $6 \%$ new bone formation and indicated its use as a successful bone graft mixture for sinus augmentation, although the absence of a control group in this study prevents an objective evaluation of the positive effect of PRP.

In our study, the clinical outcome of bone regeneration procedures and the dental implant replacement was not influenced by the addition of PRP to the bone substitute materials. The histomorphometric analysis revealed that the sinuses grafted with $\mathrm{ABB}$ alone had approximately the same percentage of augmented bone volume as that reported in similar studies (Tadjoedin and colleagues). We observed a percentage of new bone formation of $21.3 \pm 4.5 \%$ while Tadjoedin et al. (2003) reported $22.9 \pm$ $2.5 \%$ for the same conditions. However, the sinuses grafted with ABB + PRP had significantly higher amounts of bone volume. Interestingly, the amount of bone volume obtained by combining ABB with PRP $(31 \pm 5 \%)$ was similar to that reported by other authors for composite grafts combining autogenous bone with $\mathrm{ABB}$ in a $1: 1$ ratio $(30.4 \pm$ $2.8 \%$ ) (Tadjoedin et al. 2003, GalindoMoreno et al. 2007).

The increased bone regeneration rates observed with PRP were attributed to the growth factor released from platelets, as well as the fibrin network present in PRP that is believed to enhance 
osteoconduction of the bone substitute material (Marx et al. 1998). Although some authors suggest that PRP induces higher graft resorption rates in autologous bone grafts (Fennis et al. 2004, Wiltfang et al. 2004), in this study, PRP did not show any effect on the resorption of the ABB particles. Moreover, the type of bone graft did not influence either implant survival or treatment success.

There are several reports associating smoking with dental implant failure (Chuang et al. 2002, Schwartz-Arad et al. 2002). Tobacco contains several noxious substances, resulting in vasoconstriction and decreased tissue perfusion, which produces pathological ischaemia impairing wound healing. In this study, implant survival and treatment success was significantly lower in smoking patients than in non-smokers, smoking thus being an important risk factor in sinus augmentation procedures. This finding confirms previous reports that associate smoking habits with failure of implants placed in augmented sinuses (Olson et al. 2000, Kan et al. 2002, Schwartz-Arad et al. 2002).

The implant survival in augmented maxillary sinuses observed in this study was significantly higher in patients with higher amounts of residual bone height. This result is in agreement with previous studies (Geurs et al. 2001). On the other hand, the prevalence of membrane perforation observed was similar to that reported by other authors $(5.74 \%)$ (Pjetursson et al. 2008, Tonetti \& Hämmerle 2008). Furthermore, the lateral wall of the maxilla was not covered with any membrane after graft placement, and this did not affect the final outcome of the treatments.

\section{Conclusions}

PRP is not a determining factor for implant survival in sinus lifting procedures. However, this study revealed that PRP could improve the osteoconductive properties of $\mathrm{ABB}$ by increasing the volume of new bone formed, and also the handling properties of bone substitute particles. Moreover, in sinus augmentation procedures implant survival rate appears to be more influenced by the residual bone height or by tobacco than by the type of bone graft.

\section{Acknowledgements}

The authors also thank Mrs. Ascension Marin, the staff of "Clinica Dental
Alcala" and Santiago Cano Alsua for their help and support of this study.

\section{References}

Adell, R., Eriksson, B., Lekholm, U., Branemark, P. I. \& Jemt, T. (1990) Long-term follow-up study of osseointegrated implants in the treatment of totally edentulous jaws. International Journal of Oral and Maxillofacial Implants 5, 347-359.

Aghaloo, T., Moy, P. K. \& Freymiller, E. G. (2002) Investigation of platelet-rich plasma in rabbit cranial defects: a pilot study. Journal of Oral Maxillofacial Surgery 60, 11761181.

Aghaloo, T., Moy, P. K. \& Freymiller, E. G. (2005) Evaluation of platelet-rich plasma in combination with freeze-dried bone in the rabbit cranium. A pilot study. Clinical Oral Implants Research 16, 250-257.

Anitua, E. (1999) Plasma rich in growth factors: Preliminary results of use in the preparation of future sites for implants. International Journal of Oral and Maxillofacial Implants 14, 429-535.

Anitua, E., Aguirre, J. J., Algorta, J., Ayerdi, E., Cabezas, A.I, Orive, G. \& Andia, I. (2008) Effectiveness of autologous preparation rich in growth factors for the treatment of chronic cutaneous ulcers. Journal of Biomedical Material Research B Applied Biomaterials 84, 415-421.

Anitua, E., Andia, I., Ardanza, B., Nurden, P. \& Nurden, A. T. (2004) Autologous platelets as a source of proteins for healing and tissue regeneration. Thrombosis and Haemostasis 91, 4-15.

Antonaides, H. N. (1981) Human plateletderived growth factor (PDGF): Purification of PDGF-I and PDGF-II and separation of their reduced subunits. Proceedings of the National Academy of Sciences of USA 78, 7314-7317.

Bain, C. A. \& Moy, P. K. (1993) The association between the failure of dental implants and cigarette smoking. International Journal of Oral and Maxillofacial Implants 8, 609615.

Blomqvist, J. E., Alberius, P. \& Isaksson, S. (1996) Retrospective analysis of one-stage maxillary sinus augmentation with endosseous implants. International Journal of Oral and Maxillofacial Implants 11, 512-521.

Boyne, P. J. \& James, R. A. (1980) Grafting of the maxillary sinus floor with autogenous marrow and bone. Journal of Oral Surgery 38, 613-616.

Brånemark, P. I., Adell, R., Albrektsson, T., Lekholm, U., Lindström, J. \& Rockler B, (1984) An experimental and clinical study of osseointegrated implants penetrating the nasal cavity and maxillary sinus. Journal of Oral and Maxillofacial Surgery 42, 497-505.

Butterfield, K. J., Bennett, J., Gronowicz, G. \& Adams, D. (2005) Effect of platelet-rich plasma with autogenous bone graft for maxillary sinus augmentation in a rabbit model.
Journal of Oral Maxillofacial Surgery 63 370-376.

Carmagnola, D., Adriaens, P. \& Berglundh, T. (2003) Healing of human extraction sockets filled with Bio-Oss. Clinical Oral Implants Research 14, 137-143.

Cawood, J. I. \& Howell, R. A. (1991) Reconstructive preprosthetic surgery. I. Anatomical considerations. International Journal of Oral and Maxillofacial Surgery 20, 75-82.

Chuang, S. K., Wei, L. J., Douglass, C. W. \& Dodson, T. B. (2002) Risk factors for dental implant failure: a strategy for the analysis of clustered failure-time observations. Journal of Dental Research 81, 572-577.

Consolo, U., Zaffe, D., Bertoldi, C. \& Ceccherelli, G. (2007) Platelet-rich plasma activity on maxillary sinus floor augmentation by autologous bone. Clinical Oral Implants Research 18, 252-262.

Danesh-Meyer, M. J., Filstein, M. R. \& Shanaman, R. (2001) Histological evaluation of sinus augmentation using platelet rich plasma (PRP): a case series. Journal of the International Academy of Periodontology 3, 48-56.

De Bruyn, H. \& Collaert, B. (1994) The effect of smoking on early implant failure. Clinical Oral Implants Research 5, 260-264.

Donath, K. \& Breuner, G. (1982) A method for the study of undecalcified bones and teeth with attached soft tissues. The Säge-Schliff (sawing and grinding) technique. Journal of Oral Pathology 11, 318-326.

Fennis, J. P., Stoelinga, P. J. \& Jansen, J. A. (2004) Mandibular reconstruction: a histological and histomorphometric study on the use of autogenous scaffolds, particulate corticocancellous bone grafts and platelet rich plasma in goats. International Journal of Oral Maxillofacial Surgery 33, 48-55.

Froum, S. J., Wallace, S. S., Tarnow, D. P. \& Cho, S. C. (2002) Effect of platelet-rich plasma on bone growth and osseointegration in human maxillary sinus grafts: three bilateral case reports. International Journal of Periodontics Restorative Dentistry 22, 45-53.

Fürst, G., Gruber, R., Tangl, S., Zechner, W., Haas, R., Mailath, G., Sanroman, F. \& Watzek, G. (2003) Sinus grafting with autogenous platelet-rich plasma and bovine hydroxyapatite. A histomorphometric study in minipigs. Clinical Oral Implants Research 14, 500-508.

Galindo-Moreno, P., Avila, G., Fernández-Barbero, J. E., Aguilar, M., Sánchez-Fernández, E., Cutando, A. \& Wang, H. L. (2007) Evaluation of sinus floor elevation using a composite bone graft mixture. Clinical Oral Implants Research 18, 376-382.

Geurs, N. C., Wang, I. C., Shulman, L. B. \& Jeffcoat, M. K. (2001) Retrospective radiographic analysis of sinus graft and implant placement procedures from the Academy of Osseointegration Consensus Conference on Sinus Grafts. International Journal of Periodontics Restorative Dentistry 21, 517-523.

Giannobile, W. V., Hernandez, R. A., Finkelman, R. D., Ryan, S., Kiritsy, C. P., D’Andrea, M. \& Lynch, S. E. (1996) 
Comparative effects of platelet-derived growth factor-BB and insulin-like growth factor-I, individually and in combination, on periodontal regeneration in Macaca fascicularis. Journal of Periodontal Research 31, 301-312.

Gorman, L. M., Lambert, P. M., Morris, H. F., Ochi, S. \& Winkler, S. (1994) The effect of smoking on implant survival at second-stage surgery: DICRG Interim Report No. 5. Dental Implant Clinical Research Group. Implant Dentistry 3, 165-168.

Groeneveld, E. H., van den Bergh, J. P., Holzmann, P., ten Bruggenkate, C. M., Tuinzing, D. B. \& Burger, E. H. (1999) Histomorphometrical analysis of bone formed in human maxillary sinus floor elevations grafted with OP-1 device, demineralized bone matrix or autogenous bone. Comparison with nongrafted sites in a series of case reports. Clinical Oral Implants Research 10, 499509.

Hämerle, C. H., Chiantella, G. C., Karring, T. \& Lang, N. P. (1998) The effect of a deproteinized bovine bone material on bone regeneration around titanium dental implants. Clinical Oral Implants Research 9, 151-162.

Jakse, N., Tangl, S., Gilli, R., Berghold, A., Lorenzoni, M., Eskici, A., Haas, R. \& Pertl, C. (2003) Influence of PRP on autogenous sinus grafts. An experimental study on sheep. Clinical Oral Implants Research 14, 578583.

Jensen, O. T., Shulman, L. B., Block, M. S. \& Iacono, V. J. (1998) Report of the Sinus Consensus Conference of 1996. International Journal of Oral and Maxillofacial Implants 13 (Suppl.), 11-45.

Kan, J. Y., Rungcharassaeng, K., Kim, J., Lozada, J. L. \& Goodacre, C. J. (2002) Factors affecting the survival of implants placed in grafted maxillary sinuses: a clinical report. Journal of Prosthetic Dentistry 87, 485-489.

Kassolis, J. D. \& Reynolds, M. A. (2005) Evaluation of the adjunctive benefits of platelet-rich plasma in subantral sinus augmentation. Journal of Craniomaxillofacial Surgery 16, 280-287.

Kassolis, J. D., Rosen, P. S. \& Reynolds, M. A. (2000) Alveolar ridge and sinus augmentation utilizing platelet-rich plasma in combination with freeze-dried bone allograft: case series. Journal of Periodontology 71, 1654-1661.

Klongnoi, B., Rupprecht, S., Kessler, P., Thorwarth, M., Wiltfang, J. \& Schlegel, K. A. (2006a) Influence of platelet-rich plasma on a bioglass and autogenous bone in sinus augmentation. An explorative study. Clinical Oral Implants Research 17, 312-320.

Klongnoi, B., Rupprecht, S., Kessler, P., Zimmermann, R., Thorwarth, M., Pongsiri, S., Neukam, F. W., Wiltfang, J. \& Schlegel, K. A. (2006b) Lack of beneficial effects of platelet-rich plasma on sinus augmentation using a fluorohydroxyapatite or autogenous bone: an explorative study. Journal of Clinical Periodontology 33, 500-509.
Lynch, S. E., de Castilla, G. R., Williams, R. C., Kiritsy, C. P., Howell, T. H., Reddy, M. S. \& Antoniades, H. N. (1991) The effect of shortterm application of a combination platelet derived growth factors on periodontal wound healing. Journal of Periodontology 62, 458-467.

Marx, R. E., Carlson, E. R., Eichstaedt, R. M., Schimmele, S. R., Strauss, J. E. \& Georgeff, K. R. (1998) Platelet-rich plasma. Growth factors enhancement for bone grafts. Oral Surgery Oral Medicine Oral Pathology Oral Radiology and Endodontics 85, 638-646.

Mazor, Z., Peleg, M., Garg, A. K. \& Luboshitz, J. (2004) Platelet-rich plasma for bone graft enhancement in sinus floor augmentation with simultaneous implant placement: patient series study. Implant Dentistry 13, 65-72.

McCarthy, C., Patel, R. R., Wragg, P. F. \& Brook, I. M. (2003) Sinus augmentation bone grafts for the provision of dental implants: report of clinical outcome. International Journal of Oral and Maxillofacial Implants 18, 377-382.

Mish, C. E. (1990) Density of bone: effect on treatment plans, surgical approach, healing, and progressive bone loading. International Journal of Oral Implantology 6, 23-31.

Mombelli, A. \& Cionca, N. (2006) Systemic diseases affecting osseointegration therapy. Clinical Oral Implants Research 17 (Suppl. 2), 97-103.

Olson, J. W., Dent, C. D., Morris, H. F. \& Ochi, S. (2000) Long-term assessment (5 to 71 months) of endosseous dental implants placed in the augmented maxillary sinus. Annals of Periodontology 5, 152-156.

Palmer, R. M., Cortellini, P., Bosshardt, D., Cairo, F., Christgau, M., De Sanctis, M., Etienne, D., Fourmousis, I., Hughes, F., Jepsen, S., Sculean, A., Sicilia, A., Trombelli, L., Van der Velden, U. \& Yilmaz, S. (2008) Periodontal tissue engineering and regeneration: Consensus Report of the Sixth European Workshop on Periodontology. Journal of Clinical Periodontology 35 (Suppl. 8), 83-86.

Philippart, P., Daubie, V. \& Pochet, R. (2005) Sinus grafting using recombinant human tissue factor, platelet-rich plasma gel, autologous bone, and anorganic bovine bone mineral xenograft: histologic analysis and case reports. International Journal of Oral and Maxillofacial Implants 20, 274-281.

Piattelli, M., Favero, G. A., Scarano, A., Orsini, G. \& Piattelli, A. (1999) Bone reactions to anorganic bovine bone (Bio-Oss) used in sinus augmentation procedures: a histologic long-term report of 20 cases in humans. International Journal of Oral and Maxillofacial Implants 14, 835-840.

Pjetursson, B. E., Tan, W. C., Zwahlen, M. \& Lang, N. P. (2008) A systematic review of the success of sinus floor elevation and survival of implants inserted in combination with sinus floor elevation. Journal of Clinical Periodontology 35 (Suppl. 8), 216-240.

Plachokova, A. S., Nikolidakis, D., Mulder, J., Jansen, J. A. \& Creugers, N. H. (2008) Effect of platelet-rich plasma on bone regeneration in dentistry: a systematic review. Clinical Oral Implants Research 19, 539-545.

Raghoebar, G. M., Schortinghuis, J., Liem, R. S., Ruben, J. L., van der Wal, J. E. \& Vissink, A. (2005) Does platelet-rich plasma promote remodeling of autologous bone grafts used for augmentation of the maxillary sinus floor? Clinical Oral Implants Research 16, 349-356.

Rao, P. S. \& Alfidi, R. J. (1981) The environmental density artifact: a beam-hardening effect in computed tomography. Radiology 141, 223-227.

Rodriguez, A., Anastassov, G. E., Lee, H., Buchbinder, D. \& Wettan, H. (2003) Maxillary sinus augmentation with deproteinated bovine bone and platelet rich plasma with simultaneous insertion of endosseous implants. Journal of Oral Maxillofacial Surgery 61, 157-163.

Roldán, J. C., Jepsen, S., Miller, J., Freitag, S., Rueger, D. C., Açil, Y. \& Terheyden, H. (2004) Bone formation in the presence of platelet-rich plasma vs. bone morphogenetic protein-7. Bone 34, 80-90.

Roldán, J. C., Knueppel, H., Schmidt, C., Jepsen, S., Zimmermann, C. \& Terheyden, H. (2008) Single-stage sinus augmentation with cancellous iliac bone and anorganic bovine bone in the presence of platelet-rich plasma in the miniature pig. Clinical Oral Implants Research 19, 373-378.

Rosen, B. V., Hobbs, L. W. \& Spector, M. (2002) The ultarestructure of anorganic bovine bone and selected synthetic hydroxiapatites used as bone graft substitute materials. Biomaterials 23, 921-928.

Schaaf, H., Streckbein, P., Lendeckel, S., Heidinger, K., Görtz, B., Bein, G., Boedeker, R. H., Schlegel, K. A. \& Howaldt, H. P. (2008) Topical use of platelet-rich plasma to influence bone volume in maxillary augmentation: a prospective randomized trial. Vox Sanguinis 94, 64-69.

Schwartz-Arad, D., Samet, N., Samet, N. \& Mamlider, A. (2002) Smoking and complications of endosseous dental implants. Journal of Periodontology 73, 153-157.

Tadjoedin, E. S., de Lange, G. L., Bronckers, A. L., Lyaruu, D. M. \& Burger, E. H. (2003) Deproteinized cancellous bovine bone (BioOss) as bone substitute for sinus floor elevation. A retrospective, histomorphometrical study of five cases. Journal of Clinical Periodontology 30, 261-270.

Tadjoedin, E. S., de Lange, G. L., Holzmann, P. J., Kulper, L. \& Burger, E. H. (2000) Histological observations on biopsies harvested following sinus floor elevation using a bioactive glass material of narrow size range. Clinical Oral Implants Research 11, 334-344.

Tatum, H. Jr. (1986) Maxillary and sinus implant reconstructions. Dental Clinics of North America 30, 207-229.

Thor, A., Franke-Stenport, V., Johansson, C. B. \& Rasmusson, L. (2007) Early bone formation in human bone grafts treated with platelet-rich plasma: preliminary histomorpho- 
metric results. International Journal of Oral Maxillofacial Surgery 36, 1164-1171.

Thor, A., Wannfors, K., Sennerby, L. \& Rasmusson, L. (2005) Reconstruction of the severely resorbed maxilla with autogenous bone, platelet-rich plasma, and implants: 1year results of a controlled prospective 5-year study. Clinical Implant Dental Related Research 7, 209-220.

Tonetti, M. S. \& Hämmerle, C. H. (2008) European Workshop on Periodontology Group C Advances in bone augmentation to enable dental implant placement: Consensus Report of the Sixth European Workshop on Periodontology. Journal of Clinical Periodontology 35 (Suppl. 8), 168-172.

Tonetti, M. S., Pini-Prato, G. \& Cortellini, P. (1995) Effect of cigarette smoking on periodontal healing following GTR in infrabony defects. A preliminary retrospective study. Journal of Clinical Periodontology 22, 229234.

Valentini, P. \& Abensur, D. J. (2003) Maxillary sinus grafting with anorganic bovine bone: a clinical report of long-term results. International Journal of Oral and Maxillofacial Implants 18, 556-560.

Wallace, R. H. (2000) The relationship between cigarette smoking and dental implant failure. The European Journal of Prosthodonthic and Restorative Dentistry 8, 103-106.

Wallace, S. S., Froum, S. J., Cho, S. C., Elian, N., Monteiro, D., Kim, B. S. \& Tarnow, D. P. (2005) Sinus augmentation utilizing anorganic bovine bone (Bio-Oss) with absorbable and nonabsorbable membranes placed over the lateral window: histomorphometric and clinical analyses. International Journal of Periodontics Restorative Dentistry 25, 551-559.

Weibrich, G., Hansen, T., Kleis, W., Buch, R. \& Hitzler, W. E. (2004) Effect of platelet concentration in platelet-rich plasma on peri-

\section{Clinical Relevance}

Scientific rationale for the study: Although platelets are a natural source of growth factors with beneficial effects on tissue healing, the use of PRP in bone regeneration is a moot question. In this study, we compare the bone augmentation capacity of $\mathrm{ABB}$ alone and $\mathrm{ABB}$ implant bone regeneration. Bone 34, 665671.

Weibrich, G., Kleis, W. K., Buch, R., Hitzler, W. E. \& Hafner, G. (2003a) The harvest smart PreP system versus the FriadentSchültze platelet-rich plasma kit. Clinical Oral Implants Research 14, 233-239.

Weibrich, G., Kleis, W. K. \& Hafner, G. (2002a) Growth factor levels in the plateletrich plasma produced by 2 different methods: Curasan-type PRP versus PCCS System. International Journal of Oral and Maxillofacial Implants 17, 184-190.

Weibrich, G., Kleis, W. K., Hafner, G. \& Hitzler, W. E. (2002b) Growth factor levels in platelet-rich plasma and correlations with donor age, sex, and platelet count. Journal of Craniomaxillofacial Surgery 30, 97-102.

Weibrich, G., Kleis, W. K., Hafner, G., Hitzler, W. E. \& Wagner, W. (2003b) Comparison of platelet, leukocyte, and growth factor levels in point-of-care platelet-enriched plasma, prepared using a modified Curasan kit, with preparations received from a local blood bank. Clinical Oral Implants Research 14, 357-362.

Wikesjö, U. M., Razi, S. S., Sigurdsson, T. J., Tatakis, D. N., Lee, M. B., Ongpipattanakul, B., Nguyen, T. \& Hardwick, R. (1998) Periodontal repair in dogs: effect of recombinant human transforming growth factor-betal on guided tissue regeneration. Journal of Clinical Periodontology 25, 475-481.

Wiltfang, J., Kloss, F. R., Kessler, P., Nkenke, E., Schultze-Mosgau, S., Zimmermann, R. \& Schlegel, K. A. (2004) Effects of platelet-rich plasma on bone healing in combination with autogenous bone and bone substitutes in critical-size defects. An animal experiment. Clinical Oral Implants Research 15, 187193.

combined with PRP in sinus floor elevation procedures.

Principal findings: PRP can improve the osteoconductive properties of $\mathrm{ABB}$ by increasing the bone volume inside the sinuses even though this does not affect the final success of the treatment. On the contrary, residual bone height and smoking beha-
Zijderveld, S. A., Zerbo, I. R., van den Bergh, J. P., Schulten, E. A. \& ten Bruggenkate, C. M. (2005) Maxillary sinus floor augmentation using a beta-tricalcium phosphate (Cerasorb) alone compared to autogenous bone grafts International Journal of Oral and Maxillofacial Implants 20, 432-440.

Zinner, I. D. \& Small, S. A. (1996) Sinus-lift graft: using the maxillary sinuses to support implants. Journal of the American Dental Association 127, 51-57.

\section{Supporting Information}

Additional Supporting Information may be found in the online version of this article:

Table S1. Supporting information in accordance with the CONSORT Statement 2001 checklist used in reporting randomized trials.

Please note: Wiley-Blackwell is not responsible for the content or functionality of any supporting materials supplied by the authors. Any queries (other than missing material) should be directed to the corresponding author for the article.

\section{Address:}

Jesús Torres Garcia-Denche

Department of Health Sciences III;

Faculty of Health Sciences,

Rey Juan Carlos University,

28922 Alcorcón,

Madrid

Spain

E-mail: jesus.torres@urjc.es

viour are relevant factors for treatment success.

Practical implications: PRP is not a determining factor for implant survival; however, it improves both the handling and the osteoconductive properties of the graft in sinus augmentation procedures. 


\section{Author Query Form}

\begin{tabular}{ll}
\hline Journal & CPE \\
Article & 1437 \\
\hline
\end{tabular}

Dear Author,

During the copy-editing of your paper, the following queries arose. Please respond to these by marking up your proofs with the necessary changes/additions. Please write your answers clearly on the query sheet if there is insufficient space on the page proofs. If returning the proof by fax do not write too close to the paper's edge. Please remember that illegible mark-ups may delay publication.

\begin{tabular}{|c|c|c|}
\hline Query No. & Description & Author Response \\
\hline Q1 & $\begin{array}{l}\text { Author: A running head short title was not supplied; please check if this one is suitable and, if not, please supply a } \\
\text { short title that can be used instead. }\end{array}$ & \\
\hline Q2 & $\begin{array}{l}\text { Author: The reference (Misch 1990) has been changed to (Mish 1990) to match the citation in the reference list. } \\
\text { Please confirm that this is correct. }\end{array}$ & \\
\hline Q3 & $\begin{array}{l}\text { Author: The reference Branemark et al. (1994) has been changed to } \mathrm{Br}(\text { nemark et al. (1984) to match the citation in } \\
\text { the reference list. Please confirm that this is correct. }\end{array}$ & \\
\hline Q4 & $\begin{array}{l}\text { Author: The reference Valentini et al. (2003) has been changed to Valentini \& Abensur (2003) to match the citation } \\
\text { in the reference list. Please confirm that this is correct. }\end{array}$ & \\
\hline Q5 & $\begin{array}{l}\text { AUTHOR: As per style manufacture information is not allowed in the first section. Please confirm the deletion of } \\
\text { Wolhusen, Switzerland. Else cite Bio-Oss in later sections to add complete manufacture details. }\end{array}$ & \\
\hline Q6 & $\begin{array}{l}\text { Author: Reference Benezra et al. (2003) has not been included in the Reference List, please supply full publication } \\
\text { details. }\end{array}$ & \\
\hline Q7 & $\begin{array}{l}\text { Author: The reference Hammerle et al. (1998) has been changed to } \mathrm{H} \text { (merle et al. (1998) to match the citation in the } \\
\text { reference list. Please confirm that this is correct. }\end{array}$ & \\
\hline Q8 & $\begin{array}{l}\text { Author: The reference Piatelli et al. (1999) has been changed to Piattelli et al. (1999) to match the citation in the } \\
\text { reference list. Please confirm that this is correct. }\end{array}$ & \\
\hline Q9 & $\begin{array}{l}\text { Author: The reference Antoniades (1981) has been changed to Antonaides (1981) to match the citation in the } \\
\text { reference list. Please confirm that this is correct. }\end{array}$ & \\
\hline Q10 & $\begin{array}{l}\text { Author: The reference Wijesjo et al. (1998) has been changed to Wikesjö et al. (1998) to match the citation in the } \\
\text { reference list. Please confirm that this is correct. }\end{array}$ & \\
\hline Q11 & $\begin{array}{l}\text { Author: The reference Philipart et al. (2005) has been changed to Philippart et al. (2005) to match the citation in the } \\
\text { reference list. Please confirm that this is correct. }\end{array}$ & \\
\hline Q12 & $\begin{array}{l}\text { Author: The reference Galindo et al. (2007) has been changed to Galindo-Moreno et al. (2007) to match the citation } \\
\text { in the reference list. Please confirm that this is correct. }\end{array}$ & $\overline{\bar{~}}$ \\
\hline Q13 & $\begin{array}{l}\text { The reference Roldan et al. (2004) has been changed to Roldán et al. (2004) to match the citation in the reference } \\
\text { list. Please confirm that this is correct. }\end{array}$ & $\bar{\equiv}$ \\
\hline & thor: The reference Klongnoi et al. (2006) has been changed to Klo & \\
\hline
\end{tabular}




\section{Author Query Form}

\begin{tabular}{lr}
\hline Journal & CPE \\
Article & 1437 \\
\hline
\end{tabular}

\section{Dear Author,}

During the copy-editing of your paper, the following queries arose. Please respond to these by marking up your proofs with the necessary changes/additions. Please write your answers clearly on the query sheet if there is insufficient space on the page proofs. If returning the proof by fax do not write too close to the paper's edge. Please remember that illegible mark-ups may delay publication.

\begin{tabular}{|c|c|c|}
\hline $\begin{array}{c}\text { Query } \\
\text { No. }\end{array}$ & Description & Author Response \\
\hline Q14 & the reference list. Please confirm that this is correct. & \\
\hline Q15 & $\begin{array}{l}\text { Author: The reference Kassolis et al. (2005) has been changed to Kassolis \& Reynolds (2005) to match the citation } \\
\text { in the reference list. Please confirm that this is correct. }\end{array}$ & \\
\hline Q16 & $\begin{array}{l}\text { Author: The reference De Bruyn et al. (1994) has been changed to De Bruyn and Collaert (1994) to match the } \\
\text { citation in the reference list. Please confirm that this is correct. }\end{array}$ & \\
\hline Q17 & $\begin{array}{l}\text { Author: The reference Bain et al. (1993) has been changed to Bain \& Moy (1993) to match the citation in the } \\
\text { reference list. Please confirm that this is correct. }\end{array}$ & \\
\hline Q18 & $\begin{array}{l}\text { Author: The reference Wallace et al. (2000) has been changed to Wallace (2000) to match the citation in the } \\
\text { reference list. Please confirm that this is correct. }\end{array}$ & \\
\hline Q19 & $\begin{array}{l}\text { Author: The reference Cadwood \& Howell (1991) has been changed to Cawood \& Howell (1991) to match the } \\
\text { citation in the reference list. Please confirm that this is correct. }\end{array}$ & \\
\hline Q20 & $\begin{array}{l}\text { Author: The reference Tonetti et al. (2008) has been changed to Tonetti \& } \mathrm{H} \text { (mmerle (2008) to match the citation in } \\
\text { the reference list. Please confirm that this is correct. }\end{array}$ & \\
\hline Q21 & $\begin{array}{l}\text { Author: The reference Anitua (2004) has been changed to Anitua et al. (2004) to match the citation in the reference } \\
\text { list. Please confirm that this is correct. }\end{array}$ & \\
\hline Q22 & $\begin{array}{l}\text { Author: The reference Kassolis et al. }(2000,2005) \text { has been changed to Kassolis et al. }(2000) \text { and Kassolis and } \\
\text { Reynolds (2005) to match the citation in the reference list. Please confirm that this is correct. }\end{array}$ & \\
\hline Q23 & $\begin{array}{l}\text { Author: The reference Aghlaloo et al. }(2002 \text { and } 2005) \text { has been changed to Aghaloo et al. }(2002,2005) \text { to match } \\
\text { the citation in the reference list. Please confirm that this is correct. }\end{array}$ & \\
\hline Q24 & $\begin{array}{l}\text { Author: The reference Weibrich et al. (2005) has been changed to Weibrich et al. (2004) to match the citation in the } \\
\text { reference list. Please confirm that this is correct. }\end{array}$ & \\
\hline Q25 & $\begin{array}{l}\text { Author: The reference Raghobear et al. (2005) has been changed to Raghoebar et al. (2005) to match the citation } \\
\text { in the reference list. Please confirm that this is correct. }\end{array}$ & \\
\hline
\end{tabular}




\section{Author Query Form}

\section{Journal CPE \\ Article $\quad 1437$}

\section{Dear Author,}

During the copy-editing of your paper, the following queries arose. Please respond to these by marking up your proofs with the necessary changes/additions. Please write your answers clearly on the query sheet if there is insufficient space on the page proofs. If returning the proof by fax do not write too close to the paper's edge. Please remember that illegible mark-ups may delay publication.

\begin{tabular}{|c|c|c|}
\hline $\begin{array}{l}\text { Query } \\
\text { No. }\end{array}$ & Description & Author Response \\
\hline Q26 & $\begin{array}{l}\text { Author: The reference Schaff et al. (2007) has been changed to Schaaf et al. (2008) to match the citation in the } \\
\text { reference list. Please confirm that this is correct. }\end{array}$ & $\equiv$ \\
\hline Q27 & $\begin{array}{l}\text { Author: The reference Plachocova et al. (2008) has been changed to Plachokova et al. (2008) to match the } \\
\text { citation in the reference list. Please confirm that this is correct. }\end{array}$ & \\
\hline Q28 & $\begin{array}{l}\text { AUTHOR: Reference Rosen et al. (2002) has not been cited in the text. Please indicate where it should be cited; or } \\
\text { delete from the Reference List. }\end{array}$ & \\
\hline Q29 & AUTHOR: Table 7 cited in the caption of Fig. 11, but not supplied. Please check. & $\overline{\overline{\bar{v}}}$ \\
\hline Q30 & $\begin{array}{l}\text { AUTHOR: Figure } 4 \text { is if poor quality. Please check required artwork } \\
\text { specifications at http://www.blackwellpublishing.com/authors/digill.asp }\end{array}$ & $\overline{\bar{E}}$ \\
\hline Q31 & AUTHOR: Please check if the suggested caption for Supporting Information given is correct. & $\overline{\overline{\overline{\sqrt{ }}}}$ \\
\hline & & \\
\hline & & \\
\hline & & \\
\hline & & \\
\hline & & \\
\hline
\end{tabular}

